(c) EUSP, $2019 \quad|\mathfrak{e}| \quad$ ISSN 2310-3817 Vol.7 SICSIS No.1 p.124-138

3

engl

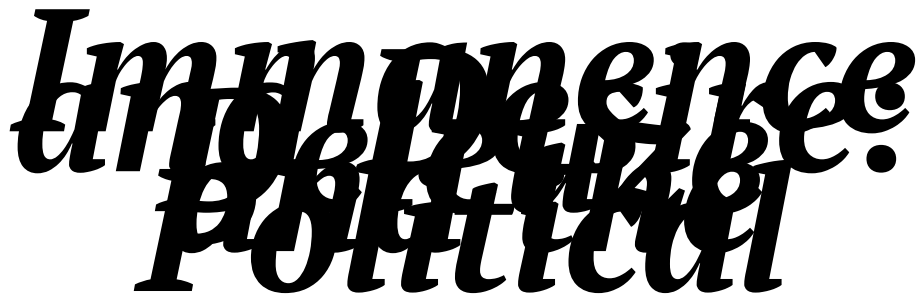

Daniel W. Smith

Professor, Purdue University, Department of Philosophy

100 N. University St., West Lafayette, USA IN 47907

E-mail: smith132@purdue.edu

\title{
Immanence and Desire: Deleuze and the Political
}

\begin{abstract}
Spinoza posed the fundamental problem of politics as a question of desire: Why do humans fight for their servitude as if it were their salvation? Why does desire desire its own repression? Gilles Deleuze and Félix Guattari take up this question in Anti-Oedipus and attempt to provide a rigorous response. Whereas Plato defined desire in terms if lack (if I desire something, it is because I lack it), Kant effected a revolution in thought by defining desire in terms of production (because I desire something, I produce it). It is this productive concept of desire that allows Deleuze and Guattari to effect a synthesis between Freud (libidinal economy) and Marx (political economy), though as I argue Deleuze and Guattari's deeper points of reference are Spinoza and Nietzsche. We conclude by analyzing Deleuze and Guattari's relation to the question of a democratic politics.
\end{abstract}




\section{Keywords}

Deleuze, Guattari, desire, Spinoza, Nietzsche, democracy

\section{Immanence and the Problem of Desire}

One of the fundamental questions of political philosophy was formulated by Baruch Spinoza in the preface to his Theological-Political Treatise (1991 [1670]): Why do humans fight for their servitude as though it were their salvation? ${ }^{1}$ Put differently, this is a question of desire, or what is sometimes called "voluntary servitude": How can desire desire its own repression? Why do slaves consent to their slavery, or the exploited to their exploitation? Spinoza poses the problem in the context of the Roman principle dulce et decorum est pro patria mori ("It is a sweet and noble thing to die for one's country"): Why do people consider it the highest honor to give their blood and their lives for the glory of their country-or even one man (the tyrant or despot)-or even for our collective "freedom"? In Anti-Oedipus, Gilles Deleuze and Félix Guattari pose the problem in less militaristic terms: "What is astonishing is not that some people steal or that others occasionally go out on strike," they write, "but rather that all those who are starving do not steal as a regular practice, and all those who are exploited are not continually out on strike" (Deleuze and Guattari 1983 [1972]: 29; see also 257, 356, 379). How and why, in other words, do we-all of us, you, me-invest ourselves in a social system that nonetheless exploits us, that separates us from what we can do, that makes us miserable?

In one sense, the answer to this question is obvious, and has already been given by Wilhelm Reich in his work on the problem of fascism. The masses supported Hitler, Stalin, and Mao, neither out of ignorance, nor because they were prey to an illusion, nor because they believed their "interests" were best defended by such dictators. "No, the masses were not innocent dupes; at a certain point, under a certain set of conditions, they desired fascism, and it is this perversion of the desire of the masses that needs to be accounted for" (Ibid.).

1 People "will fight for their servitude as if for salvation, and count it no shame, but the highest honor, to spend their blood and their lives for the glorification of one man” (Spinoza 1991 [1670]: 3). 


\section{The Freud-Marx Synthesis}

It is this problematic of desire that Deleuze attempts to address in Anti-Oedipus. Famously, Anti-Oedipus was often read as one of the first successful attempts to bring about a synthesis of Karl Marx and Sigmund Freud (the "masters of suspicion"), both of whom appealed to "unconscious" determinations of the political sphere. In very general terms, for a Marxist, human discourses are determined by underlying relations of production, and the explicit "ideology" of a discourse must be made apparent by relating it to production in such a way that its class interest becomes discernible. For a Freudian, conscious representations are symptomatic of unconscious desires, and the task of analysis is to cure the subject by making these unconscious mechanisms apparent. The whole problem was how to relate these two "unconscious" economies together-the political economy of Marx and the libidinal economy of Freud. Earlier attempts had turned to extrinsic notions such as introjection and projection: I introject social determinations into my personal unconscious, and social determinations are themselves collective projections of our individual psyches. How such mechanisms worked, however, were difficult to explain.

Deleuze suggests that it was Pierre Klossowski, in his 1972 book Living Currency, who found a way, through Friedrich Nietzsche, to solve the problem of the relation between Marx and Freud, between political economy (the social) and libidinal economy (the individual): "by discovering [...] how the affects or drives form part of the infrastructure itself" (Deleuze and Guattari 1983 [1972]: 63, own emphasis added). ${ }^{2}$ Deleuze and Guattari take up this Nietzschean schema in Anti-Oedipus: what they call "desire" is nothing other than the state of our impulses and drives. We desire what we desire because our drives and affects have been constituted or "machined" in that way. "The drives," Deleuze tells us, "are simply the desiring-machines themselves," they are the way in which desire in engineered in sociopolitical terms (Deleuze and Guattari 1983 [1972]: 35). When Deleuze says that the drives are themselves economic, that they are already part of what Marx called the infrastructure, he is reiterating, in his own manner, Nietzsche's thesis that our drives are always assembled (ordered and ranked) by morality.

2 See also Klossowski: "They themselves [the drives] create their own repression” (2017 [1970]: 48). Deleuze confirmed his indebtedness to Klossowski in a letter dated 21 April, 1971: "You introduce desire into the infra-structure or inversely, which amounts to the same thing, you introduce the category of production into desire: this seems to me of an immense importance; for it is the only means to get out of the sterile parallelism Marx-Freud, Money-Excrement ... Once again, I'm following you." Cited in Wilson (2006: 15). 
It is this theme that I would like to explore briefly in this paper: the political problem of desire (How can desire desire its own repression? How can the exploited desire their own exploitation?) at a level where our own affects and drives are seen to be determined in a direct political manner (they are part of the infrastructure), rather than being seen as some sort of instinctual or "natural" substratum of our being that somehow has to be "sublimated" or "projected" outward in order to enter into the domain of the political.

\section{Desire and the Problem of Immanence}

Posing the problem of desire in this way is what Deleuze calls an immanent conception of desire, and it entails, indeed, something of a revolution in the traditional conception of desire (at least in the philosophical tradition). What exactly does it mean to speak of an immanent conception of desire? The fact is that philosophy has almost always linked desire to a field of transcendence, from Plato and the Greeks, through Augustine and Christianity, to Hegel and Freud: if you desire something, it is because you lack that something. If desire exists, it is the sign, it is the very fact, that lack exists. Desire is the desire for what one does not have; it is therefore defined as the function of a field of transcendence (since what one does not have transcends my field of immanence).

In this vision of transcendence, desire necessarily oscillates between two poles. The negative pole signifies the fundamental absence of the desired object (which, in Plato, is the Good): whereas need is a relative lack that is satisfied as soon as the object is attained, desire is an irremediable ontological lack that is unrealizable (a lack of Being). This is the tragic vision of desire: humans are incomplete and riddled with deficiencies, and desire is the sign of this incompleteness, the mark of their tragic misery. The ultimate object of desire is always missing, it is never in its place, it is never found, it is always transcendent.

But there is also a positive pole to this desire: conscious of this lack, humanity seeks to acquire its Being by making its desire coincide with the order of the Good that desire itself furthers. This is the dramatic dimension of desire, the theme of the quest, the incessant search of the restless soul (Augustine). Plato's initial postulate of the lack of Being is thus pregnant with a series of intermediate postulates that lead to the ultimate postulate of a recovered Being. But since desire, left to itself, cannot direct Being toward its realization, the Republic will indicate the conditions (culture, knowledge) capable of making desire coincide with the essence it lacks. $^{3}$

3 Plato (1925: 206a, 205e). This analysis of the transcendent concept of desire 
Summarizing this tradition of transcendence, Clement Rosset has written: every time desire is defined by lack, "the world acquires as its double some other sort of world, in accordance with the following line of argument: there is an object that desire feels the lack of; hence the world does not contain each and every object that exists; there is at least one object missing, the one that desire feels the lack of; hence there exists some other place that contains the key to desire (missing in this world)" (Rosset 1970: 37). What then would it mean to think of desire in purely immanent terms? We are so used to this transcendent conception of desire-if we desire, it is because we lack something-that it is difficult to conceive of an alternative, or even to conceptualize what an immanent formula of desire would look like.

\section{Kant's Copernican Revolution in Practical Philosophy}

Now oddly enough, it was Immanuel Kant who brought about this revolution in the theory of desire. In the Critique of Practical Reason, Kant offers a definition of desire that breaks entirely with the previous tradition. Desire, he says, is "a faculty which, by means of its representations, is the cause of the actuality of the objects of those representations" (Kant 1957 [1790]: III, n1). This is a remarkable definition of desire, since it sees desire as something productive. This is indeed Kant's Copernican Revolution in practical philosophy: desire is no longer defined in terms of lack (I desire something because I do not have it) but rather in terms of production (I produce something because I desire it). But what exactly is Kant saying here? At a first view, Kant's definition of desire as productive seems somewhat untenable and even magical: I have a representation, and desire is the faculty that is capable of bringing about the reality of its object. The more one reads in Kant, the more insistent Kant becomes with this definition: "Practical reason," he says elsewhere, "is concerned not with objects in order to know them, but with its own capacity to make them real" (Kant 1993 [1788]: 93, "Elucidation of the Analytic"). What does Kant mean here?

Kant is in fact making two points about practical and political philosophy. On the one hand, Kant defines desire in the way he does because the problem of freedom concerns the operation by which a free being can be said to be the cause of an action: in acting freely, the agent produces something that is not reducible to the causal determinism of the mechanistic world. In that sense, desire indeed seems to be capable of bringing about the reality of its representations: I want to steal your car, and desire

is indebted to Dominique Grisoni (1982: 169-82). 
is the faculty capable of bringing about the reality of that action. This is why Kant says that practical reason "has to do with a will which is a causal agent so far as reason contains its determining ground" (Kant 1993 [1788]: 93 "Elucidation of the Analytic"). On the other hand, Kant knows fully well that a "real" object can only be produced through an external causality and external mechanisms. For Kant, the reality of the object produced by desire is, in the end, merely a psychic reality. Desire may indeed be productive, but what it produces "in reality" are mere fantasies: psychic realities such as hallucinations, deliriums, superstitions, imaginary objects, and so on. Thus, despite the Copernican revolution, the Kantian conception of desire still remains tied to the transcendent conception of desire: if desire lacks a real object, then its own reality still tied to an "essence of lack," and it is this lack that produces the fantasized object. Freudian psychoanalysis, of course, would provide a plausible explanation of desire as the production of fantasies. ${ }^{4}$

Now I would argue that one of the primary aims of Deleuze and Guattari's book Anti-Oedipus is to draw out the full implications of Kant's definition of desire as productive. "If desire produces," Deleuze writes, "its product is real [and not merely a fantasy]. If desire is productive, it can be productive only in the real world and can produce only reality" (Deleuze and Guattari 1983 [1972]: 26). The critical reversal brought about by AntiOedipus is to view the process of desire as itself a "material economic reality," and not merely a psychic reality. ${ }^{5}$ In other words, political economy (Marx) and libidinal economy (Freud) are one and the same thing. For Deleuze, this is what it means to speak of a purely immanent conception of desire: desire is primary, it is an active power that is not derived from a lack of an absent object; it is not bivalent, having a positive and negative pole, but is purely positive; and finally, desire is not produced (because of

4 For Freud, the unconscious is incapable of reproducing (or rediscovering) primary (childhood) situations where the drives could obtain complete satisfaction; failing to realize its desire (repression), the unconscious produces an imaginary object that functions as a compensatory double of reality, a mental production functioning alongside real production that "suspends" desire, thanks to the compensatory situations (sublimation) constitutive of civilization. "This means that the real object that desire lacks is related to an extrinsic natural or social production, whereas desire intrinsically produces an imaginary object that comes to double reality, as if there were 'a dreamed object behind every real object,' or a mental production or real productions” (Deleuze and Guattari 1983: 25-26). Like Plato, Freud still finds the true cause of desire in a primal lack, and divides it into a positive pole (Eros, the desire for life and reproduction) that passes into the real, invests the social field, and supports the effects of moralization and culture (sublimation); and a negative pole (Thanatos, the desire for death and destruction) that takes cover in the unconscious and undertakes the patient weaving of the fantastic signs of its gratification.

"There is no particular form of existence that could be called 'psychic reality”" (Deleuze and Guattari 1983: 25). 
a lack), it is productive, the desired thing is not desired because it is absent, but on the contrary it is real because desired. But how does Deleuze justify this extraordinary claim that desire produces the real?

\section{Deleuze's Inversion of Kant}

For Kant, the essential question concerns the higher form that each faculty is capable of (a form which is no longer merely "pathological"). A faculty has a higher form when it finds within itself the law of its own exercise (and thus functions autonomously). The higher form of desire, for Kant, is what he calls the "will." The will is the same thing as desire but raised to its higher form. Desire becomes will when it is determined by the representation of a pure form, namely, the moral law, which is the pure form of a universal legislation, that is, the categorical imperative. Practical reason concerns the will, which has reason as its determining groundunder such conditions we are acting freely. But significantly, in order to function, the moral law requires the intervention of the three great transcendent Ideas as its postulates. Freedom, as the "fact" of morality, implies the cosmological Idea of a supra-sensible world, independent of any sensible condition; in turn, the abyss that separates the noumenal Law and the phenomenal world requires the intermediary of an intelligible author of sensible Nature or a "moral cause of the world" (the theological Idea of a supreme being, or God)-an abyss that can only be bridged through the "postulate" of an infinite progress, which requires the psychological Idea of the immortality of the soul. In other words, having denounced the transcendent Ideas of Soul, World, and God in the first Critique, Kant resurrects each of them, one by one, in the second Critique, and gives them a practical determination.

Anti-Oedipus remains an incomprehensible book as long as one does not see its overall structure as an attempt, on Deleuze's part, to rewrite the Critique of Practical Reason from the viewpoint of a strictly immanent theory of Ideas. What would a purely immanent theory of desire look like? What if one did not appeal to the moral law and the transcendent Ideas that serve as its postulates, and which instead synthesized desire with a conception of Ideas as purely immanent? This is precisely what Deleuze does in the opening two chapters of Anti-Oedipus: the three syntheses by which he and Guattari define "desiring-machines" are in fact the three same Ideas that Kant defines as the postulates of practical reason-Self, World, and God-but now stripped entirely of their transcendent status, to the point where neither God, World, nor Self subsist. As Deleuze had already put the point in Logic of Sense: "The divergence of the affirmed series forms a 'chaosmos' and no longer a World; the aleatory point which traverses them forms a counter-self, and no longer a self; disjunction pos- 
es as a synthesis exchanges its theological principle of diabolic principle [...] The Grand Canyon of the world, the 'crack' of the self, and the dismembering of God" (Deleuze 1990 [1969]: 176). In Anti-Oedipus, Deleuze gives a purely immanent characterization of the three syntheses-connection (Self), conjunction (World), and disjunction (God)-and then shows how desire itself is constituted by tracing out series and trajectories following these syntheses within a given social assemblage.

Now to flesh out this idea of an immanent conception of desire, I would like to turn briefly to the two thinkers that are its most important precursors-not Marx and Freud, but rather Spinoza and Nietzsche, whom Deleuze has always taken to be his primary philosophical inspirations. Spinoza and Nietzsche are the two great exemplars of immanence in philosophy. In our context here, this means that they were the two thinkers to put forward the idea that our affects and drives are directly political-in other words, that the libidinal economy and political economy are one and the same thing. Let me just say, then, a brief word about each of them before returning, finally, to the way Deleuze brings this to bear on his problematic of desire.

\section{Spinoza and the Affects}

Spinoza, for his part, drew a famous distinction between "affections" (affectio) and "affects" (affectus). Consider someone in the midst of their everyday life: I walk down a city street on a Sunday afternoon; I greet one or two acquaintances I pass on the way; I sit in a park in the warmth of the afternoon sun, reading a book; in the evening, I meet a friend in a café for a coffee and a sandwich; afterwards, I feel slightly ill and head home. Spinoza suggests that we can make a "geometrical" analysis of our everyday life along these two axes of affections and affects. On the one hand, an "affection" indicates the state of my body insofar as it is affected by another body, which is determined in the mind as a succession of ideas. While walking down the street, I see Peter, and then Paul-a succession of ideas. Later, while sitting in a park, I see the sun, and then the sun sets and it becomes dark-another succession of ideas or affections.

On the other hand, each of these affections also determines what Spinoza will call an "affect." I see Peter, but we've had a falling out, and I feel uneasy seeing him, so I veer away and avoid him. Then I see Paul, an old friend who is charming and amiable; I walk up to him and greet him, feeling reassured and content. There is still a succession of ideas herethe idea of Peter and the idea of Paul-but there is also something else: a variation in what Spinoza calls my "force of existing" (vis existendi) or “power of acting” (potentia agendi) (1966 [1677]). 
When I see Peter, my power of acting decreases; when I see Paul, it increases. The heat of the sun in the park increases my power of acting, the sunburn I develop decreases it. Food increases my force of existing, but my stomach ache later decreases it. Here, we are no longer in the domain of the external affection on my body (or the idea in my mind), but rather in the domain of the affects: our power of acting or force of existence is increased or diminished in a continuous manner, on a continuous line, depending on my external affections (that is, the way other bodies affect me). The affects define a regime of continuous variation that is constantly rising and falling-joy is a rising affect, sadness a falling affectand which marks a lived transition or lived passage from what Spinoza calls one "degree of perfection" to another (Spinoza 1996, 31-32). Indeed, this language of rises and falls in affective intensity is Spinoza's anticipatory language of mania and depression-what is today called "bipolarity".

This is why Spinoza, like Gottfried Leibniz, liked to speak of the soul as a spiritual automaton, since nine-tenths of what we do we do automatically. ${ }^{6}$ As spiritual automata, there are in us ideas and affections that succeed one another (affections or affectio), while at the same time, our "power of acting" or "force of existence" is increased or diminished in a continuous manner, on a continuous line (affects or affectus). Spinoza no doubt admits an instance of what we like to call "agency"-for him, the ethical task is to reach the point where we can be the source of our own affections and affects, a kind of auto-affectivity-but the givenness of our existence places us in a position in which we are primarily a multiplicity of affections and affects. This is obviously why a neurobiologist such as Antonio Damasio can find in Spinoza such a kindred spirit in Looking for Spinoza: Joy, Sorrow, and the Feeling Brain (Damasio 2003), and why William Conolly, in Neuropolitics, was able to show in a profound manner the direct link between the political and the neurological dimension of affects and affections (Connolly 2002). Lars Tønder's exploration of the political import of the affect of hilaritas, as described by Spinoza is, in my opinion, a profound development of this idea of the direct political import of the affects (Tønder 2005). (I might note in passing that, in film, it was the great French director Robert Bresson who most profoundly explored the idea of the "spiritual automaton" in the cinema, preferring to use in his films, not actors, but what he called "models" or "Vigilambulists," somnambulists in the waking state.)

6 "So far as I know they [the ancients] never conceived the soul (as we do here) as acting according to certain laws, like a spiritual automaton" (Spinoza 1985 [1677]: 37). Leibniz, for his own reasons, would appeal to the same image: "The soul is a most exact spiritual automaton" (Leibniz 1969: 495). 


\section{Nietzsche and the Drives}

The thinker who most directly took up and developed Spinoza's theory of affectivity, albeit in a highly independent manner, was Nietzsche. When Nietzsche famously proposed to use the body (rather than the mind) as a model for philosophy, he understood this not only in the sense of the extensive body (the organism), but more importantly, in terms of the intensive body (or what Deleuze, following Antonin Artaud, would call the "body without organs"). The intensive body is the locus of a system of drives: every individual contains within itself "a vast confusion of contradictory drives” (Nietzsche 1967 [1901]: §259), and as such must be understood as a multiplicity and not an identity. This is the source of Nietzsche's doctrine of perspectivism ("there are no facts, only interpretations")-but it is our drives that interpret the world and are perspectival, and not our egos or our conscious opinions. The point is not that I have a different perspective on the world than others, but that each of us has multiple perspectives on the world within ourselves because of the multiplicity of our drives-drives that are contradictory among themselves, and in a constant struggle or combat with each other. "Within ourselves," Nietzsche writes, "we can be egoistic or altruistic, hard-hearted, magnanimous, just, lenient, insincere, can cause pain or give pleasure" (quoted in Parkes 1996: 291-92, own emphasis added). Nietzsche developed his parallel concept of the will to power at the level of the drive: "Every drive is a kind of lust to rule, each one has its perspective that it would like to compel all the other drives to accept as a norm” (Nietzsche 196: §481).

If Nietzsche considered the ego or the "I" to be a kind of fiction, it is because, when we think "we" are fighting a drive, or combating our passions, it is in fact one drive that is combating another drive (Nietzsche 1997 [1881]: §109). The ego (or intellect) simply takes sides in this combat of the drives: when we talk about the "I," we are simply indicating which drive, at the moment, is strongest and sovereign. Thus, what do I mean when I say "I am trying to stop smoking"-even though that same I is constantly going ahead and continuing to smoke? It simply means that my conscious intellect is taking sides and associating itself with a particular drive. It would make just as much sense to say, "Occasionally I feel this strange urge to stop smoking, but happily I've managed to combat that drive and pick up a cigarette whenever I want.” Here again, there is an automatism at work: instinctively, Nietzsche says, we tend to take our predominant drive and for the moment turn it into the whole of our ego, placing all our weaker drives perspectivally farther away, as if those other drives weren't me but rather something else, something other inside me, a kind of "it" (hence Freud's idea of the "id," the "it"-it is clear he derived this idea from Nietzsche) (Nietzsche 1966 [1886]: §19). When we talk about the "I," we are simply indicating which drive, at the moment, is 


\section{Daniel W. Smith}

sovereign, strongest; the feeling of the I is always strongest where the preponderance [Übergewicht] is, flickering from drive to drive.

But the drives themselves remain largely unknown to the conscious intellect, and one can see where this renders the link between affectivity and politics somewhat problematic. The liberal tradition of political philosophy, at least, tends to focus on the individual, and moreover, the individual's conscious will, its ability to act as an agent in the political and legal realms - to be able to choose, to vote, to purchase economic goodsin short, to have a conscious intentionality that can assume responsibilities. To talk about the direct link between the affects and the political is to take us into the domain of the unconscious-in the broadest sense of that term-which propels us into a radically new way of conceiving of the political.

In this regard, Nietzsche perhaps went further than Spinoza in conceiving of affect-politics relations. One of the primary functions of what we call "morality" is to establish an order or ranking among our various drives. "Wherever we encounter a morality," Nietzsche says, "we also encounter valuations and an order of rank of human impulses... [...] Now one and now another human impulse and state held first place and was enobled because it was esteemed so highly" (Nietzsche 1974 [1882]: §116, § 115). In a warrior morality, for instance, the affect of aggressiveness would be a virtue, and meekness a vice; whereas in a Christian morality, the affects of meekness (turn the other cheek, do not resist) is a far higher value than aggression. When Nietzsche enquires into the genealogy of morality, he is inquiring into the conditions of any particular moral ranking of the impulses: why certain impulses are selected for and certain impulses are selected against. He famously argued that the value inherent in most moral rankings is the value of what he called the "herd instinct" (Nietzsche 1968: 462), that is, the impulses that were selected for were those that tended to serve the instincts of the community, the furtherance of the "species" (for instance, "unegoistic" drives such as self-abnegation and self-sacrifice). More generally, Nietzsche argues that herd morality is an instinct against Life: a paradoxical situation in which Life turns against itself. But there is no distinction between nature and artifice here: it is not as if the mechanisms of morality and culture could somehow be removed, and the drives could exist in a "free," "unbound," or "liberated" state: there is no such thing, except perhaps as an Idea (in the Kantian sense). The impulse toward the herd, toward the community, is itself a drive, in competition with the other drives: we never leave the domain of the drives.

Kant liked to say that we can never get beyond our representations; Nietzsche surmises that what we can never get beyond is the reality of the drives (Nietzsche 1966 [1886]: §36). Even when philosophers talk about the combat of reason against the drives - which is one of the oldest themes 
in philosophy-we are still not leaving the domain of the drives: what we call "reason," for Nietzsche, is nothing more than a certain "system of relations between various passions" (Nietzsche 1967 [1901]: §387), a certain ordering of the drives. This is true even in Plato, for whom the "reasonable" soul was a soul whose drives were ordered in a harmonious or "harmonic" fashion; Nietzsche's own criteria will be to prefer an ordering that emphasizes and prefers the active and productive drives. Our drives and impulses, in other words, are always assembled or arranged in different ways, in different individuals, in different moralities-which is why Nietzsche always insisted that there are a plurality of moralities (Nietzsche 1974 [1882]: §116). What he found lacking in his time was an adequate comparative study of moralities.

\section{Deleuze and the Question of Democratic Politics}

In both Nietzsche and Spinoza, then, one finds this equation of our affective economy with political economy, and this allows to return, finally, to our opening question, which in fact could be seen as the fundamental problematic of a purely immanent conception of desire: How can desire desire its own repression? From a theoretical viewpoint, the response to this question has in fact already been given: if desire is already part of the infrastructure, if our affects and drives are in fact the working parts of every social assemblage, then it is inevitable that, from the start, our fundamental desire is for the social system of which we are a part. Our affects and drives are always already part of the cogs and machinery of the social system. It is thus not surprising that we often suffer our exploitations and humiliations willingly. And this is precisely the reason that the political question has to be more properly posed at the level of unconscious desire than at the level of preconscious interest (much less conscious decision). Advertisers and marketers have long ago learned this lesson: marketing attempts to change our affects directly, quite apart from our interests. It is equally a cliché to say that, in elections, people often vote against their interests: modern elections are fought at the level of desire, that is, at the level of affects and drives. Immanent desire never exists in a free or unbound state, but only in a machined and engineered assemblage, rich in interactions.

This is why Deleuze insisted, in contrast to Foucault, for instance, that desire is a more basic political concept than power. The fundamental theme of an immanent conception of desire is that "desire organizes power: it organizes the system of repression" (Deleuze and Guattari 2004: 264). To give one example: our department were recently giving oral examinations to graduate students who were taking their comprehensive exams. All the students were nervous; some passed, and some did not; 


\section{Daniel W. Smith}

and those who did not pass felt terrible. But why did they all voluntarily subject themselves to this ordeal? Because in each case, their drives of the students were already constituted in such a way that they actually desired to participate in this tension-producing and ego-deflating institutional ritual, and not simply because they had calculated the desirability of the consequences of passing in terms of a calculus of utility. Their drives were already part of the infrastructure.

The converse problem would be: How is revolution possible?" (Patton 2000: 69; see also Sibertin-Blanc 2016: passim). Desire not only desires and constructs its own repression (voluntary servitude); it is equally the case that the constitution of a new position of desire (or the drives)what Deleuze calls a "deterritorialized" desire (Deleuze and Guattari $1983,136)$ - is by its very nature a threat to any social assemblage, whose fundamental aim is always to code the movements of desire. The question of revolution (or at least social change) also has to be posed at the level of desire or the drives. As Paul Patton writes, "if by revolution is meant a rupture with the causal determinations previously at work in a given social field, then 'only what is of the order of desire and its irruption accounts for the reality this rupture assumes at a given moment, in a given place”" (Patton 2000: 69, citing Deleuze 1977: 377).

This is why, finally, I would suggest that Deleuze has a fundamentally ambiguous relationship to "democratic" politics-which Spinoza, for his part, defended quite explicitly in the Tractatus (1998). Deleuze himself rarely speaks of democracy, except as a particular constitution of states. ${ }^{7}$ The problem of political organization that confronted him was derived directly from this immanent theory of desire: If desire is always assembled by a concrete social formation, he asked, would it be possible to conceive of a positive social formation that is at once external to State formation (democratic or otherwise) and, more importantly, that is actively constituted along a vector of "deterritorialized" desire? It was not until $A$ Thousand Plateaus (Deleuze and Guattari 1987 [1981]) that Deleuze was able to formulate a response to this question in his conception of the "nomadic war machine" (an ambiguous name, since the social formation Deleuze was analyzing has strictly contingent relations to both nomadism and war) (Deleuze and Guattari 1987 [1981]: 351-423). This raises a number of interesting questions of political organization: What is the difference between Spinoza's radical democracy and Deleuze's war machine? Why does Deleuze define the organizational principle of the war machine as a "numerical composition" of people? What relation, if any, would such a composition of people have to a democratic politics? Is it possible to

For a broader analysis of Deleuze's relationship to the question of democracy, see Mengue (2003), as well as Patton's analysis of Mengue's book (Patton 2005; reprinted in Patton 2010: 161-84). 
conceptualize democracy apart from the apparatus of the State? If so, is there a way of bringing together the Spinozistic theory of democracy with the Deleuzian theory of the war machine? These are questions Deleuze has bequeathed to future thinkers, and I myself suspect that the differences between Spinoza and Deleuze can be traced to their differing ontologies of immanence. Although Deleuze is, in a sense, a Spinozist, his own ontology could perhaps be characterized as a Spinozism minus substance, that is, as a purely modal and differential ontology. It was perhaps Spinoza's retention of the theory of substance that prevented him from pushing his ontology of immanence to its conclusion-that is, to its Deleuzian conclusion. Whatever their differences, what Spinoza and Deleuze agree on is the intimate link between ontology and politics, as opposed to any political theory that would grounds its ethical principles in a domain outside ontology, which is precisely the political position of transcendence.

\section{References}

Connolly, William (2002). Neuropolitics: Thinking, Culture, Speed. Minneapolis: University of Minnesota Press.

Damasio, Antonio (2003). Looking for Spinoza: Joy, Sorrow, and the Feeling Brain. Orlando, FL: Harcourt.

Deleuze, Gilles (1977). “Nomad Thought.” In The New Nietzsche: Contemporary Styles of Interpretation, ed. David B. Allison, 142-49. Cambridge, MA: MIT Press.

Deleuze, Gilles (1990). Logic of Sense [1969]. Trans. Mark Lester with Charles Stivale, ed. Constantin V. Boundas. New York: Columbia University Press.

Deleuze, Gilles, and Félix Guattari (2004). “On Capitalism and Desire” (interview). In Desert Islands and Other Texts, ed. Sylvre Lotinger, trans. Michael Taormina, 26273. Los Angeles, CA: Semiotext(e)

Deleuze, Gilles, and Félix Guattari (1983). Anti-Oedipus [1972]. Trans. Robert Hurley, Mark Seem, Helen R. Lane. Minneapolis: University of Minnesota Press.

Deleuze, Gilles, and Félix Guattari (1987). A Thousand Plateaus . Trans. Brian Massumi. Minneapolis: University of Minnesota Press.

Grisoni, Dominique (1982). “Onomatopoeia of Desire.” In Theoretical Strategies, ed. P. Botsman, 169-82. Sydney: Local Consumption.

Kant, Immanuel (1957). Critique of Judgment [1790]. Trans. James Creed Meredith, Oxford: Oxford University Press.

Kant, Immanuel (1993). Critique of Practical Reason [1788]. Trans. Lewis White Beck. New York: Macmillan.

Klossowski, Pierre (2017). Living Currency [1970]. Trans. Vernon Cisney, Nicolae Morar, Daniel W. Smith. London: Bloomsbury. 


\section{Daniel W. Smith}

Leibniz, Gottfried (1969). “Clarification of the Difficulties which Mr. Bayle has Found in the New System of the Union of Soul and Body” In Philosophical Papers and Letters, 2nd ed., ed. Leroy E. Loemker, 492-97. Dordrecht: D. Reidel.

Mengue, Philippe (2003). Deleuze et la question de la démocratie. Paris: Editions L'Harmattan.

Nietzsche, Friedrich (1966). Beyond Good and Evil [1886]. Trans. Walter Kaufmann. New York: Random House.

Nietzsche, Friedrich (1967). Will to Power [1901]. Trans. Walter Kaufmann and R. J. Hollingdale. New York: Random House.

Nietzsche, Friedrich (1968). “Genealogy of Morals.” In Basic Writings of Nietzsche I, 2, ed. and trans. Walter Kaufmann, 499-599. New York: Modern Library.

Nietzsche, Friedrich (1974). The Gay Science [1882]. Trans. Walter Kaufmann. New York: Vintage.

Nietzsche, Friedrich (1997). Daybreak: Thoughts on the Prejudices of Morality [1881]. Eds. Maudemarie Clark and Brian Leiter, trans. R. J. Hollingdale. Cambridge: Cambridge University Press.

Parkes, Graham (1996). Composing the Soul: The Reaches of Nietzsche's Psychology. Chicago: University of Chicago Press.

Patton, Paul (2000). Deleuze and the Political. New York: Routledge.

Patton, Paul (2010). Deleuzian Concepts: Philosophy, Colonization, Politics. Stanford: Stanford University Press.

Patton, Paul (2011). “What is Deleuzean Political Philosophy?” In Crítica Contemporánea. Revista de Teoría Politica 1: 115-26.

Patton, Paul (2014). “Deleuze and Democratic Politics.” In Radical Democracy: Politics Between Abundance and Lack, eds. Lars Tønder and Lasse Thomassen, 50-67. Manchester: Manchester University Press.

Plato (1925). Symposium. Trans. W. R. M. Lamb. Loeb Classical Library No. 166. Cambridge, MA: Harvard University Press.

Rossett, Clement (1971). Logique du pire. Paris: Presses Universitaires de France.

Sibertin-Blanc, Guillaume (2016). State and Politics: Deleuze and Guattari on Marx. Trans. Ames Hodges. Los Angeles, CA: Semiotext(e).

Spinoza, Baruch (1985). "The Emendation of the Intellect" [1677]. In The Collected Works of Spinoza, ed. and trans. Edwin Curley, 3-45. Princeton: Princeton University Press.

Spinoza, Baruch (1996). Ethics [1677]. Trans. Edwin Curley. London: Penguin.

Spinoza, Baruch (1998). Theological-Political Treatise [1670]. Trans. Samuel Shirley. Indianapolis: Hackett.

Tønder, Lars (2005). Experiences of Tolerance: Immanence, Transcendence, Hilaritas. PhD Dissertation submitted to Johns Hopkins University, USA.

Wilson, Sarah (2006). “Pierre Klossowski: Epiphanies and Secrets.” In Pierre Klossowski, ed. Anthony Spira and Sarah Wilson, 4-17. London: Hatje Cantz. 